\title{
EXPLORING BRAND POSITIONING AND HOTEL PERSONA TROUGH WOM AND CONTENT BY TEXT ANALYSIS
}

\author{
Tri Widarmanti*1 and Gadang Ramantoko*) \\ *) School of Economics and Business, Telkom University \\ J1. Telekomunikasi No 1, Bandung 40257, Indonesia
}

\begin{abstract}
Hotel management will concentrate on addressing difficult challenges and finding new ways for hotels to succeed in today's changing market world. Online customer reviews can be used to reflect the degree of differentiation between hotel brands and understanding the hotel industry's market structure through text analytics. The purpose of this study is to discover and demonstrate how customer online reviews (WOM and content), in the hospitality industry using text analysis can be used to explore brand positioning of hotel persona. This study gathered 4.215 online reviews one of hotel at Bandung city from year of 2015 - 2019, the methodology used the approach of text classification, quantitative analysis of text. This study found the category of visitors who stay the most are comes from family category and romantic vacation category, while the target visitors expected by the hotel are from business traveler's category. Most customer state the word "family" when mentioning the hotel. Children, family, pool, zoo are the words most often discussed in customer reviews. This study findings can be used as an insight into what are the things that generate a satisfying experience and strengthen brand positioning of the hotel. In the future, it would be interesting to gathered data from multiple e-commerce application, and combining ontology-learning-based text mining and psychometric techniques to translate online hotel's reviews into a hotel's positioning map, capturing the relationship between product of hotel and reviewer effectively.
\end{abstract}

Keywords: online review, brand positioning, text analytics, customer perceived value, hotel persona

\begin{abstract}
Abstrak: Manajemen hotel harus fokus untuk mengatasi tantangan yang sulit dan menemukan cara agar hotel dapat sukses pada kondisi pasar yang terus berubah. Ulasan secara online dari kastamer dapat digunakan untuk mencerminkan posisi merek hotel dan memahami struktur pasar industri hotel dengan menggunakan teks analitik. Tujuan dari penelitian ini adalah untuk menemukan dan mendemonstrasikan bagaimana customer online reviews (WOM dan konten) pada industri perhotelan dengan menggunakan teks analitik, untuk mengeksplorasi posisi merek dan persona hotel. Penelitian ini memproses 4.215 online review salah satu hotel di kota Bandung periode tahun 2015 - 2019. Data diolah menggunakan analisis kuantitatif data tekstual dengan pendekatan klasifikasi teks. Studi ini menemukan bahwa kategori pengunjung yang menginap terbanyak berasal dari kategori wisatawan keluarga dan kategori wisatawan liburan romantis, sedangkan target pengunjungyang diharapkan oleh hotel adalah dari kategori wisatawan bisnis. Anak-anak, keluarga, kolam, kebun binatang merupakan kata-kata yang paling sering dibahas dalam review kastamer, dan kata "keluarga" merupakan kata yang ditekankan sebagai pernyataan. Temuan studi ini dapat digunakan hotel untuk meningkatkan kepuasan pelanggan dan memperkuat serta mengeksplorasi posisi merek hotel yang telah ditentukan sebelumnya oleh hotel. Untuk penelitian di masa yang akan datang, akan lebih menarik jika data yang diambil berasal dari beberapa e-comerce, dan menggabungkan text mining berbasis ontology dengan teknik psikometri untuk menterjemahkan review online kastamer hotel ke dalam peta positioning hotel serta menghubungkan review online dengan produk hotel secara efektif.
\end{abstract}

Kata kunci: online review, brand positioning, text analytics, customer perceived value, hotel persona

\footnotetext{
${ }^{1}$ Corresponding author:

Email: triwidarmanti@telkomuniversity.ac.id
} 


\section{INTRODUCTION}

Social media and content created by consumers on the Internet continue to grow and have an impact on the hotel industry, online travel reviews appear as a powerful source of information in influencing consumer prepurchase evaluations of hotels, this trend highlights the need for greater understanding of the impact of online reviews consumers to consumer attitudes and behavior (Browning et al. 2013). The extraordinary growth of social media and consumer-generated content on the Internet has inspired the development of data analytics to understand and solve real-life problems. Current technological advances have given customers the freedom to provide hotel reviews on social media.

Hospitality industry has been recognized as the place where consumers like to share their experiences in detail. Data contains customer's journey before, during or after being in the hotel. Word of mouth (WOM) communication is a major part of online consumer interaction, especially in an online community environment. Online reviews from consumers as a form of electronic-WOM is experiencing rapid development (Brown, Broderick and Lee, 2007). A negative review from customer affected potential action of positive direction, expectations, suggestions, content improvement and warnings and it may prevent other potential customers to visit the destination (Vásquez, 2011).

Hotel management will concentrate on addressing difficult challenges and finding different ways for hotels to succeed in today's growing market world. Hotel needs to improve decision-making in computerized management software by the use decision software and market intelligence systems (Sharda et al. 2016). The American hotel chain, Denihan Hospitality Group, uses IBM Data Analytics software to maximize profits and revenues in 3,450 rooms and Denihan analyzes their own data with data from review sites, blogs, and social media. Companies can figure out what their guests like and dislike, as well as optimize offers and room rates according to their customers. The result is, they can doubled the occupancy of room during the 2013 United Nations Assembly Week event (Marketeer, 2015).

Experience and satisfaction of hotel guests are exciting to study and research, since hotel guest experience and satisfaction play an important role in its contribution to satisfaction, loyalty, repurchase, word of good mouth, and increase hotel profits (Xiang et al. 2015). It is important to study the feedback from customer customer satisfaction evaluation for improvement in the future (Utama et al. 2020).

Krawczyk and Xiang (2016) used text analytics approach to online reviews for represents a potentially powerful data source that can be used to provide insights into how brands are perceived. Online customer reviews can be used to reflect the degree of differentiation between hotel brands, and therefore a valuable source for understanding the hotel industry's market structure. Text analytics can help to improve understanding related to decision making in the hospitality industry.

Our interest to one of hotel at Bandung City, Tjokro Hotel because its environment characteristics: 1 . Situated in a shopping recreational long-street; 2 . Situated near a well-established hospital; 3. Situated in the middle of Lembang and City Center. The hotel introduces a 3 stars economy class hotel and proclaims itself as the most suitable accommodation choice for business travelers, and one of the best comfort hotel at competitive prices in its segment.

Perceptual hotel brand positioning - A brand is wellpositioned when it enjoys a competitive advantage based on strong core competencies. Brands are built to influence consumer emotions as well as to create more specific associations between brand component and selected facets of quality (Aaker, 1996). It requires more than just associating a property with a name and logo or designing a marketing campaign to establish a strong hotel brand in the hospitality industry Cai and Hobson study (2004, as cited in Hu and Trivedi, 2020). Within the hospitality industry, many hotel companies often use their brand's popularity to positively influence customers ' overall view of the importance associated with purchasing the company's goods and services within order to increase revenues (O'Neill and Matilla, 2010). Hotel brand carries promise from the management to its customers and acts as antecedent to customers' satisfaction (Salim, 2014) If the promise exceeds customers' expectation, then hotel brand gets stronger. Hotel brand also interacts with its environment.

In hospitality industry, Attractions, Destination, facilities and lodging such as hotels, hostels and retreats are the information important to the traveler's plans explored and checked, thus being an essential phase on decision- 
making process, and online reviews define the traveler's experience of staying in hotels and show the traveler's evaluations of such hotels (Sánchez-Franco et al. 2019). If the travelers are satisfied by what they know about the hospitality programs, their revisiting intentions would be affected greatly (Park et al. 2007). The growth of online consumer reviews offers new opportunities for understanding consumer perceptions of hotel products such as hotel brand positioning.

Consumer perception toward satisfaction is characterized by the number of stars received by the Providers. The star ratings can be viewed as an aggregate indicator of the customer's post-consumption experience. Service providers then can score their service as an average number of ratings. Apart from star ratings, can also analyze feedback with a focus on user-generated content (UGC) (Sánchez-Franco et al. 2019). UGCs are generated by consumers. UGC conveyed by existent travelers appears to be added autonomous, empathetic and positive (Wilson and Sherrell, 1993; Bickart and Schindler, 2001; Huang and Chen, 2006; Gretzel and Yoo, 2008; Sparks et al. 2016 as cited in (SánchezFranco et al. 2019). UGC is playing an increasingly significant role in consumer expectations and buying intentions, especially in relation with travel services Wu et al. study (2017), as cited in Sánchez-Franco et al. 2019).

Social media has been found to play an important role in affecting the way consumers search, decide and book hotels (Gupta, 2019). Social media helps consumers in collecting information about products and services, assessing alternatives and making their choices, this helps hospitality marketing and management related to a better understanding of the impact of social media on the hotel customer decision making process. In the lodging context, the concept of brand positioning may be "measured" by customer perceptions of facilities, services offered and the price paid for the stay (Aaker and Shansby, 1982) support by (Neirotti et al. 2016) who stated that analysis of reviewers' demographic and personal traits is a good way for customers to weight and analyze existing online reviews because they can focus on reviews that best fit with their own preferences. Creating a clear market identity for distant hotels from other rivals by offering and transmitting unique tangible and intangible benefits which a rival considers difficult to replicate Anderson et al. study (1999), as cited in $\mathrm{Hu}$ and Trivendi, 2020). The efforts typically map the competitive landscape by analyzing consumer views on selected attributes with respect to pre-identified brands to establish re-positioning strategy or market positioning, it is essential to investigate the positioning of the hotel brand from the viewpoint of customers and to examine the performance of different competing hotels in a market in order to achieve a consistent positioning with a strong market orientation (Plumeyer et al. 2017). Recent research in the hospitality industry has often discussed the role of hotel products and strategic problems in the countryside using survey data (Brown and Ragsdale, 2002). Online applications of UGC are already starting to overtake survey-based market analysis methods, online comments are considered as the primary source for unique UGCs. Online usergenerated reviews are great practical use, first, they have become an inevitable part of the decision-making process of consumers on product purchase, second, they collectively form a low cost and efficient feed-back channel, which helps businesses to keep track of their reputation and to improve the quality of their products and services (Hai et al. 2017). Marine and Clavé (2015) found that huge content analysis of reliable source information, UGC data, are very useful in applying Business Intelligence to destination management, both to establish and evaluate marketing strategies and to enhance branding and positioning policies among tourism and marketing organizations. $\mathrm{Hu}$ and Trivedi (2020) applicate of large-scale UGC to explore brand placement and strategic landscaping in a more detailed and thorough way, they define market positioning and competitive environment by concurrently employing consumer preferences and opinions in a common setting, employing customer expectations to define market positioning and competing categories.

This study wanted to demonstrate how customer online reviews (WOM and content) in the hospitality industry can be used to explore brand positioning and hotel persona using text analysis. The text comments from customer reviews are compared to other reviews on the website, this study investigate the comment classes and verify whether the classification succeeds divide the comments into Good, Fair and Unknown comments, and finally extract factors that lead to Good, Fair comments and Unknown comments, and finally extract factors that lead to Good, Fair comments and Unknown comments. The result can be used for hospitality industry by focusing on the factors that really matter for the customers, generate a satisfying experience, and strengthen brand positioning of the hotel. 


\section{METHODS}

This research has been inspired by online reviews of customers in the hospitality industry which will be analyzed using Quanteda (quantitative analysis of textual data) as one of text analysis tools. We collected the data from Traveloka - Indonesia (one of tourism marketplace that provides hotel booking service online). Scrape data online reviews from one of hotel at Bandung city for about 4.215 online reviews from the year 2015 -2019. Using Phantomjs web-scraping. All the text comments are text in english. The example comments are shown in Figure 1.

The methodology (Figure 2) used the approach for text classification (Ghosh and Sanyal, 2018), it is start from data collection, text preprocessing, exploratory data analysis, and evaluation. After collecting the data, for improving the quality of raw data text in to a clean text dataset, it is necessary to do preprocessing the data (Vijayarani et al. 2015) text preprocess activity are removing punctuation, digits, capitalization, extra area - white space, tokenization, and de-pluralization the terms, weed out unnecessarily popular phrases, delete a collection of specific stop words. This study classify customer review in to three terms Good, Fair and Unknown, captured the number of times each word in the corpus appears within each comment and visualized the word through world-cloud, do the scatter plot frequency of the most common words, and see the relative frequency - how often does a word occur as a proportion of all occurring words - by the category of the value, we detect words that distinguish between the comment categories, and look at words associated with comments based on review type.

Feature generation or feature construction is the process of creating new features from one or multiple existing features, in this study the feature generation are column review, visit category, review id, author, date publish, and rating value, as an origin features and the extracted features are sentiment over-all and review type. those features are related with origin feature. Feature selection tries to find the optimal subset of a given feature set, feature selection is essentially equivalent to the problem of finding the optimal subset of a given set, calculate the evaluation score for each possible subset, after done in choosing feature generation and selection, the process continue to identify the hidden pattern use text mining.

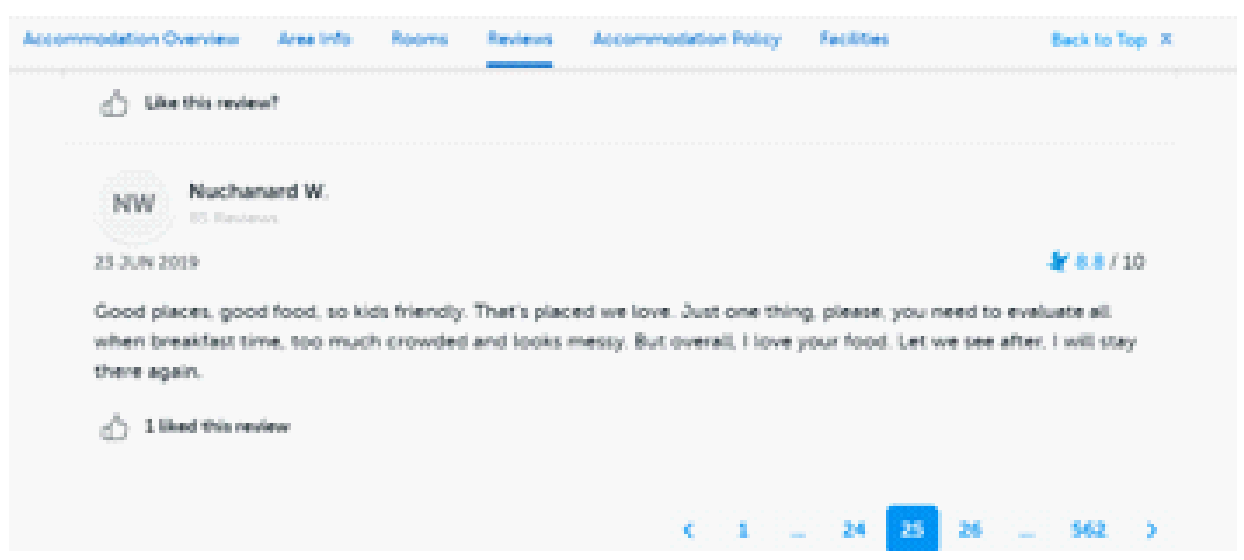

Figure 1. One sample comment from collected data

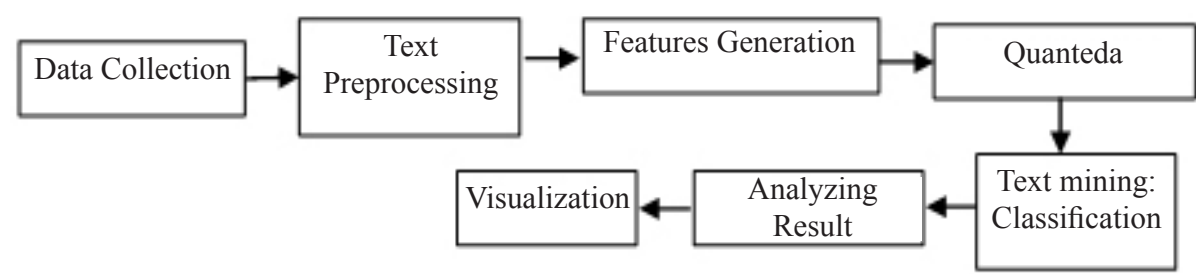

Figure 2. Methodology (Ghosh and Sanyal, 2018) 
Text mining describes as a specific field of data mining involving the analysis of textual material to identify the hidden patterns that can be turned into actionable knowledge (Fan et al. 2006), applying text mining required mine the textual data. This study applied $\mathrm{R}$ 3.6.1 and use quantitative analysis of textual data "quanteda", "tidyverse", "RColorBrewer", "Scales". Quanteda used forcreating and managing text, extracting features from text, and analyzing those features using quantitative methods (Benoit et al. 2018).

This study analyze the result by taking the most frequent words from the text comment, and see 10 tops words most used word in the review hotel, and we distinguishing words to detect words by comment categories, and also show the keyword in category of the value Fair, Good and Unknown comments, see how the words associated with comments based on review type, as a representation of data and information and to communicate relationship of data with image, we use word of cloud, scatterplot, and histogram.

e-WOM (online review - consumer comment) as UGC and unstructured data, comment and rating of costumer can be trust to show the consumer evaluative process, the experience of staying in hotels and the evaluations of the hotels. The unstructured data of UGC from comment and rating of customer will be analyzed to find the insight and see by what means the information useful for hotel positioning and how our hotel persona fit with customer visitor category using Quanteda. The research framework in Figure 3.

Reviews can be used to boost customer satisfaction and analyzing consumer views with respect to pre-identified brands to establish a market positioning by build several assumptions, first guests' satisfaction impact consumers and business organizations considerably (Niu and Fan, 2018). Second assumption, many customers do not offer reviews but give ratings, which leads us to equate blank reviews with words describing such blank reviews. Third assumption, customer visitor can define hotel persona - the aspect of hotel's character that is presented to or perceived by customer. Pandey (2009) identify the parent brand personalities as perceived customer, brand personality is the set of human characteristics associated with a brand Aaker's study (1997), as cited in Pandey, 2009) the association may consist of demographics variables, lifestyle, personality traits and cultural. Brand personality develops the interaction between the brand, service, product, organization, and the customers (Kang and Sharma, 2012) Brand persona is one of first step to take to connect with target of customer. Positioning of the hotel brand from the perspective of customers is also important to achieve a consistent positioning with a solid market orientation (Plumeyer et al. 2017).

\section{RESULTS}

Our dataset is contained amount of data users and reviews. Preprocessed, the data was cleaned, and patterns established. For about 4.215 online reviews from the year 2015 - 2019, the number of low rating $(1<$ 8 ) is only 105 reviews, document-feature matrix shows 4.215 documents. Preprocess (manual classification) contains 432 Fair reviews, 3.678 Good reviews and 105 Unknown reviews, 6.148 words features with 99.8\% sparse, and shows us 10 tops words (room, breakfast, clean, service, stay, children, food, family, comfortable, facilities, friendly, pool, mini-zoo and nice) see Figure 4.

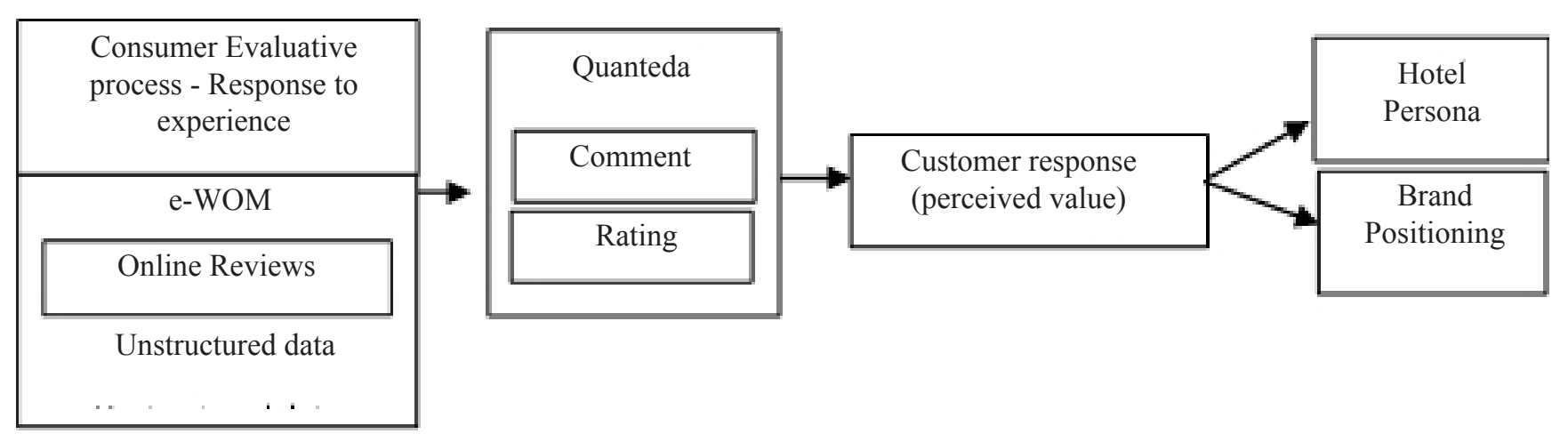

Figure 3. Research framework 
The relative frequency - how often does a word occur as a proportion of all occurring words - by the category of the value (Fair, Good and Unknown), Figure. 5 shows the most frequent words by comment type Fair and Good and Unknown, distinguishing words to detect words that distinguish between the comment categories, by a comparison word-cloud, words of playground, location, pool, family, zoo have Good terms, and words of room, water, towel, wall, bed, staff, check-in shows in Fair terms.

Word cloud with a measure of the "keyness" statistics of words in each group. In a statistical sense, compares the differential associations of keywords in a target and reference group, identifying words which appear significantly more frequently in a sample than would be expected given their overall frequency in the corpus, the frequency of the word in the target group, in the reference group (everything else), and the frequency of all other words in the target group and in the reference group shows in Figure 6, words of room, breakfast, service, food, are the example of the words that have comment type in term of Fair and Good, while word of family, comfort, friend and zoo is Good term comment type.

Figure 7 shows the words that associated with comments based on review type, the most comment by category visit are coming from family vacation category there are 2.711 comments, from business travel category are 294 comments, from romantics vacation category are 262 comments, from shopping category are 105 comments, and from no mention category are 798 comments

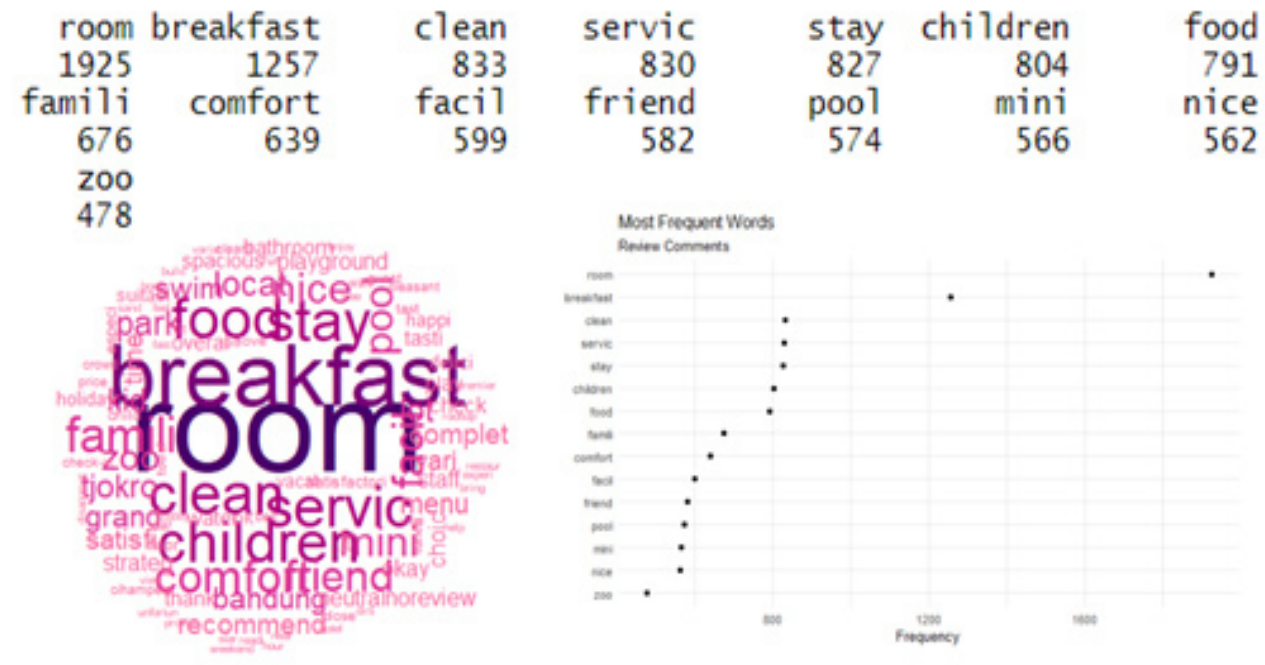

Figure 4. Most used words in the hotel reviews

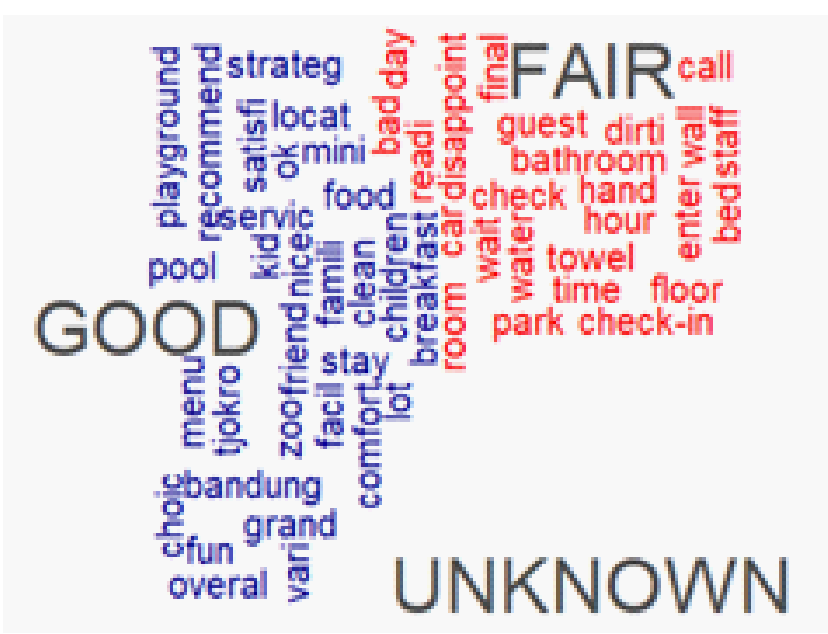

Figure 5. World cloud distinguishing words good, fair and unknown reviews 


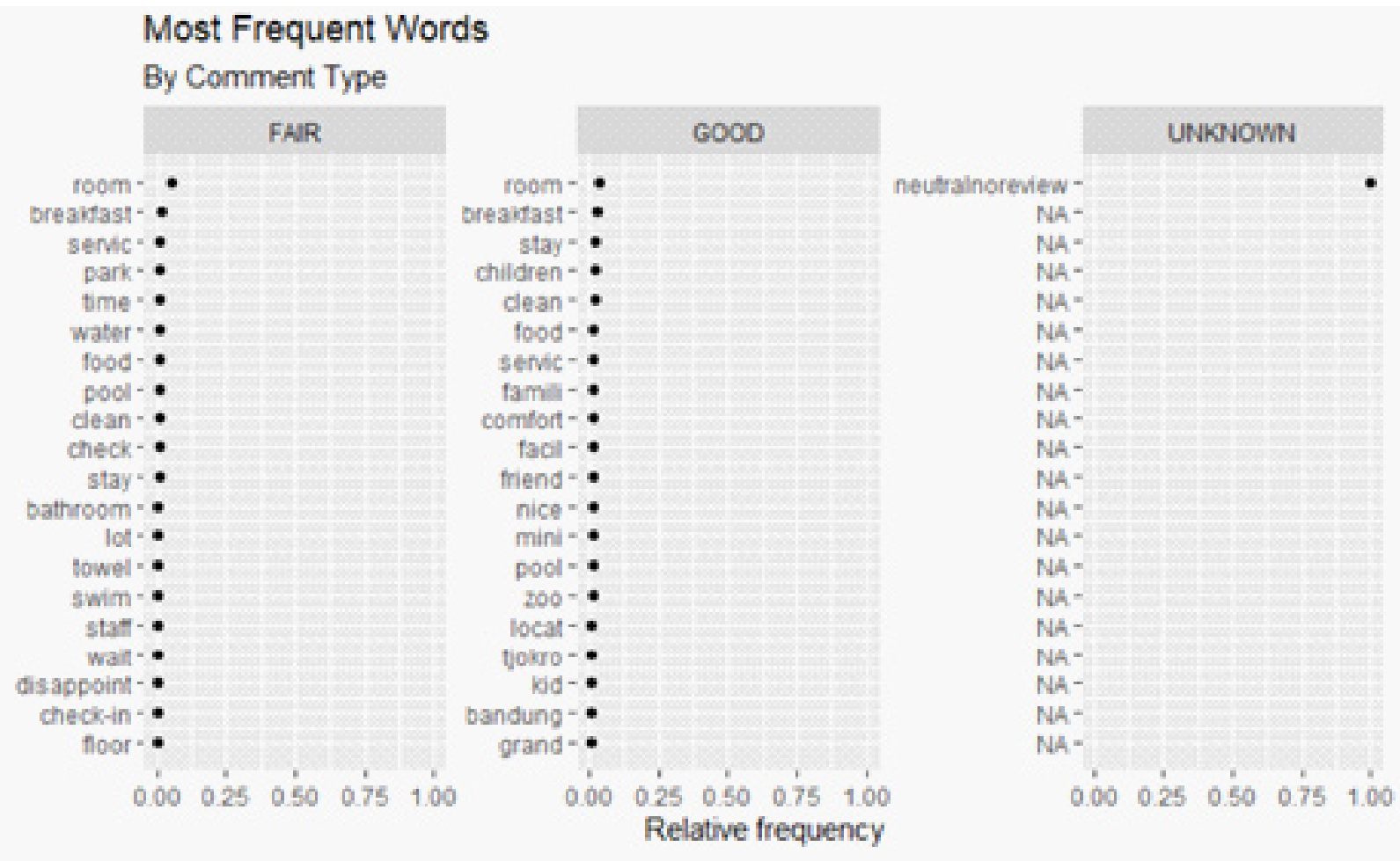

Figure 6. Keyword in fair, good and unknown sentiment overall

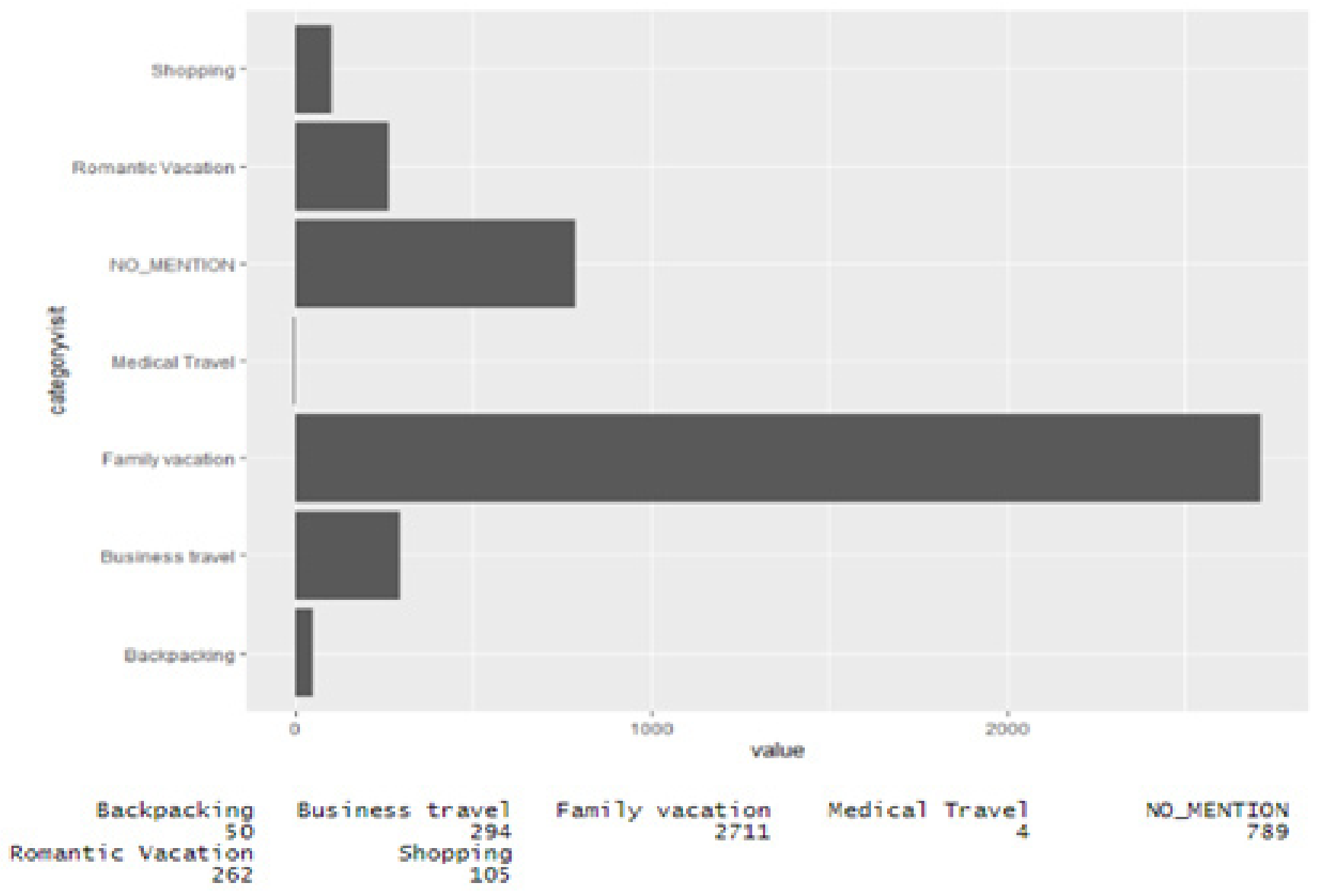

Figure 7. Most frequent comments base on review type 
Figure 8 is the term frequency - inverse document frequency that shows which words are classified as positive, mixed, satire, and none, and which words are statements from consumers. Word of breakfast, menu, service, food, facilities are the words that classified as positive terms. Word of "room" and "breakfast" are the most word that classified in a positive, mixed and satire, while the word of "family" "clean" "service" "comfort" is the most of word that costumer mention as a statement.

\section{Managerial Implications}

Customer reviews play a substantial role in a hotel's persona which directly affects its valuation (Sisodia et al. 2020). This study findings can be used as insight into what are the things that generate a satisfying experience and strengthen brand positioning of the hotel, boost customer satisfaction and exploring consumer views with respect to pre-identified brands to establish a hotel positioning. Hotel management can improve and review the words that classified as Fair in relation to the hotel's product and services and see another opportunity from visitor category - family visitor and romantic vacation visitor. The online consumer reviews offer new opportunities for understanding consumer perceptions of hotel products such as hotel brand positioning $\mathrm{Hu}$ and Trivedi (2020).

\section{CONCLUSIONS AND RECOMMENDATIONS}

\section{Conclusions}

Text analysis used quantitative method has been conducted to determine words that represent qualitative rating of the hotel and the major concern or features, and supplementary services that visitors consider when evaluating and assessing a hospitality service. The result of text data analysis shows words that represent qualitative rating of the hotel are breakfast seen from the most frequent words that mentioned in all the reviews, these words are room, food, cleanliness, service, children, stay, comfortable, family, nice, friendly, facilities, and location. The major concern of feature and supplementary services that hotel guest consider when assessing the hotel seen from the most frequent words by comment type Fair, Good and Unknown, these words are room, breakfast, food, cleanliness, service, children as. For Blank reviews with the rating are established most by customers who come to hotels for the purpose of shopping in a shopping center near the hotel, consumers not submitted comments but ratings only for the hotel, there are 102 customers with blank reviews with 0 rating and 172 customers with average 8.8 rating point (in good term of sentiment overall).

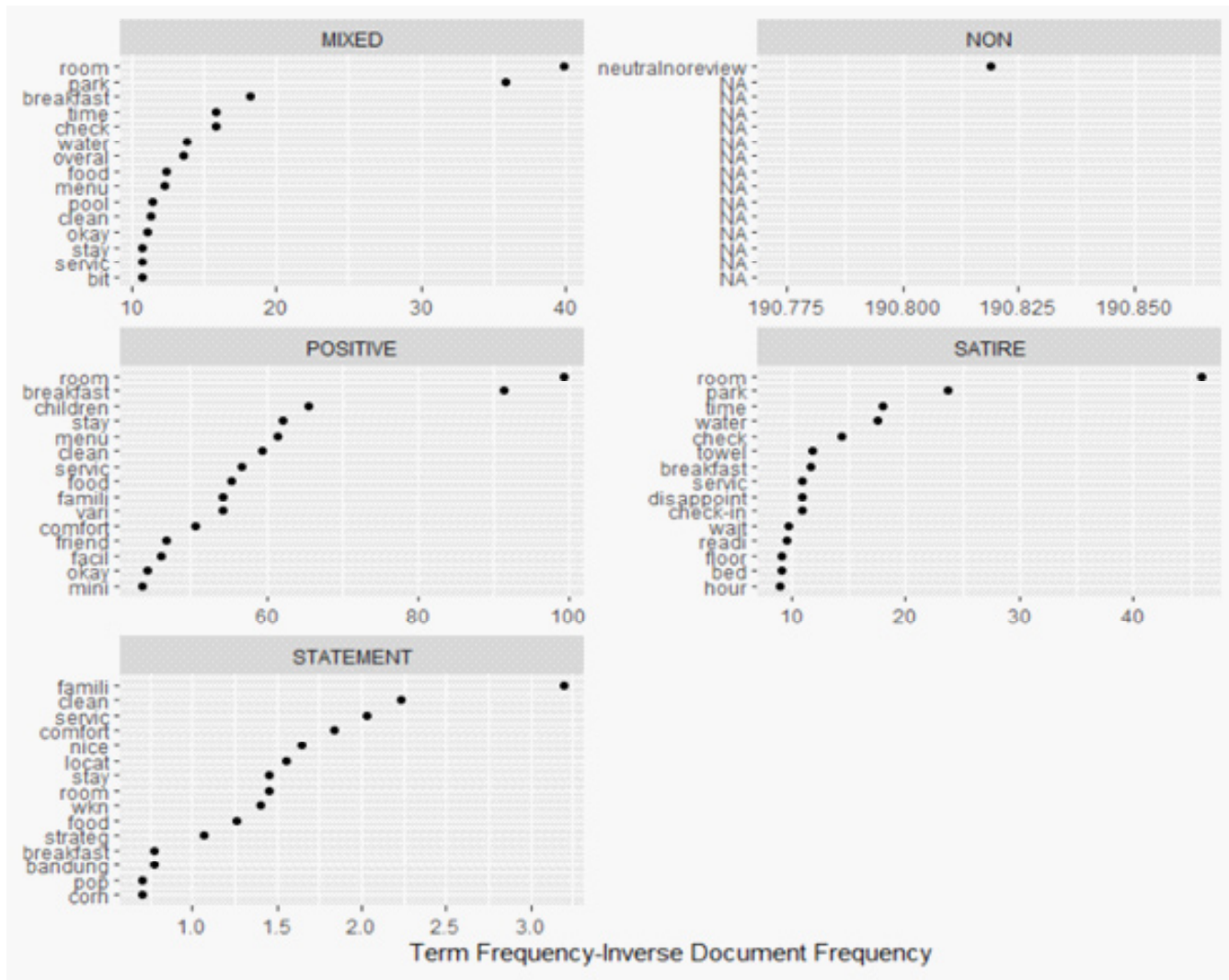

Figure 8. Term frequency - inverse document frequency 
Data shows most of customer's visitor category are from family vacation, no mention, romantic vacation and business travel categories. Word of "family" is the most of word that costumer mention as a statement. Word of Children, family, facilities, pool and zoo are the words that often appear match with visitor category. The targeted visitor hotels category that match with hotels positioning is business traveler, while the most customer's visitor category shows coming from family vacation and romantic vacation category. Word of family is the most of word that costumer mention as a statement and word of children, family, facilities, pool and zoo are the words that often appear match with visitor category.

\section{Recommendations}

The hotel's positioning proclaim as 3 star's economy class hotel, that has market segment business traveler, and be the most suitable accommodation choice for business travelers, and one of the best hotel comfort at competitive prices in its segment. According to the result of this study, the most of customer's visitor category are from family vacation, and romantic vacation, family is the word that mentioned as a statement and children, family, facilities, pool and zoo are the words that frequently be found match with visitor category. This is a useful information for the hotel to boost customer satisfaction and pre-identified hotel's positioning and persona.

Our limitation in this study is the data collected only from online reviews of one hotel in one e-commerce application that serve a hotel booking. For the research in the future it would be more interesting to gathered data from multiple e-commerce application, this study recommend to combining ontology-learning-based text mining and psychometric techniques to translate online hotel's reviews into a hotel's positioning map using Moon and Kamakura (2017) framework to capture the relationship between product of hotel and reviewer effectively and define the attributes to determine the positioning map via ontology learning.

\section{REFERENCES}

Aaker DA. 1996. Measuring brand equity across products and markets. California management review 38(3): 102-120. https://doi. org/10.2307/41165845
Benoit $\mathrm{K}$ et al. 2018. quanteda: An $\mathrm{R}$ package for the quantitative analysis of textual data. Journal of Open Source Software 3(30): 774. https://doi. org/10.21105/joss.00774

Brown JR, Ragsdale CT. 2002. The competitive market efficiency of hotel brands: An application of data envelopment analysis. Journal of Hospitality \& Tourism Research 26(4): 332-360. https://doi. org/10.1177/109634802237483

Brown J, Broderick AJ, Lee N. 2007. 'Word of mouth communication within online communities: Conceptualizing the online social network. Journal of interactive marketing 21(3): 2-20. https://doi.org/10.1002/dir.20082

Browning V, So KKF, Sparks B. 2013. The influence of online reviews on consumers' attributions of service quality and control for service standards in hotels. Journal of Travel \& Tourism Marketing 30(1-2): 23-40. https://doi.org/10.1080/1054840 8.2013 .750971

Ghosh M, Sanyal G. 2018. Performance assessment of multiple classifiers based on ensemble feature selection scheme for sentiment analysis. Applied Computational Intelligence and Soft Computing 2018. https://doi.org/10.1155/2018/8909357

Hai $\mathrm{Z}$ et al. 2017. Analyzing sentiments in one go: a supervised joint topic modeling approach. IEEE Transactions on Knowledge and Data Engineering 29(6): 1172-1185. https://doi. org/10.1109/TKDE.2017.2669027

Hu F, Trivedi RH. 2020. Mapping hotel brand positioning and competitive landscapes by textmining user-generated content. International Journal of Hospitality Management 84: 102317. https://doi.org/10.1016/j.ijhm.2019.102317

Kang A, Sharma H. 2012. Using Brand Personality to enhance brand trust and perceived value: An empirical study of the brand Lux. AsiaPacific Journal of Management Research and Innovation 8(3): 323-335. https://doi. org/10.1177/2319510X1200800312

Krawczyk M, Xiang Z. 2016. Perceptual mapping of hotel brands using online reviews: a text analytics approach. Information Technology \& Tourism 16(1): 23-43. https://doi.org/10.1007/ s40558-015-0033-0

Marketeer. 2015. Mengapa Hotel Harus Menerapkan Analisis Big Data? https://Marketeers.com. [1 Nov 2019]

Marine-Roig E, Clavé SA. 2015. Tourism analytics with massive user-generated content: A case 
study of Barcelona. Journal of Destination Marketing \& Management 4(3):162-172. https:// doi.org/10.1016/j.jdmm.2015.06.004.

Moon S, Kamakura WA. 2017. A picture is worth a thousand words: Translating product reviews into a product positioning map. International Journal of Research in Marketing 34(1):265-285. https:// doi.org/10.1016/j.ijresmar.2016.05.007.

Neirotti P, Raguseo E. 2020. Mitigating resource dependence on internet visibility providers: Exploring complementarity effects in the positioning of small hotels on online intermediaries. Information \& Management p. $103279 . h t t p s: / /$ doi.org/10.1016/j. im.2020.103279.

Niu RH, Fan Y. 2018. An exploratory study of online review management in hospitality services. Journal of Service Theory and Practice https:// doi.org/10.1108/JSTP-09-2016-0158.

O'Neill JW, Mattila AS. 2010. Hotel brand strategy. Cornell Hospitality Quarterly 51(1): 27-34. https://doi.org/10.1177/1938965509352286.

Pandey A. 2009. Understanding consumer perception of brand personality. Available at SSRN 1441824. https://doi.org/10.2139/ssrn.1441824.

Park DH, Lee J, Han I. 2007. The effect of on-line consumer reviews on consumer purchasing intention: The moderating role of involvement. International Journal of Electronic Commerce 11(4): 125-148. https://doi.org/10.2753/ JEC1086-4415110405.

Sánchez-Franco MJ, Navarro-García A, RondánCataluña FJ. 2019. A naive Bayes strategy for classifying customer satisfaction: A study based on online reviews of hospitality services. Journal of Business Research 101: 499-506. https://doi. org/10.1016/j.jbusres.2018.12.051.

Sharda R, Delen D, Turban E. 2016. Business intelligence, analytics, and data science: a managerial perspective. Pearson.

Sisodia DS et al. 2020. Performance Evaluation of Learners for Analyzing the Hotel Customer Sentiments Based on Text Reviews. In Performance Management of Integrated Systems and its Applications in Software Engineering (pp. 199-209).https://doi.org/10.1007/978-98113-8253-6_20.

Utama H, Sukardi S, Djatna T. 2020. The Evaluation of Customer Satisfaction Survey Follow-Up in LPPOM MUI. Indonesian Journal of Business and Entrepreneurship (IJBE) 6(2): 105-105. https://doi.org/10.17358/ijbe.6.2.105.

Vásquez C. 2011. Complaints online: The case of TripAdvisor. Journal of Pragmatics 43(6): 1707-1717. https://doi.org/10.1016/j. pragma.2010.11.007.

Vijayarani S, Ilamathi MJ, Nithya M. 2015. Preprocessing techniques for text mining-an overview. International Journal of Computer Science \& Communication Networks 5(1): 7-16. https://doi.org/10.5121/ijcga.2015.5105.

$\mathrm{Wu} \mathrm{L}$ et al. 2017. The impact of language style on consumers' reactions to online reviews. Tourism Management 59:590-596.https://doi. org/10.1016/j.tourman.2016.09.006.

Xian Z et al. 2015. What can big data and text analytics tell us about hotel guest experience and satisfaction? International Journal of Hospitality Management 44:120-130.https://doi. org/10.1016/j.ijhm.2014.10.013. 